\title{
Marie-Claude Maurel
}

\section{Gdy zmienia się system. Ścieżki rozwoju wiejskiego w Europie Centralnej*}

Streszczenie: Niniejszy artykuł przedstawia, na podstawie prac badawczych zrealizowanych w ścisłej współpracy przez Marię Halamską i Marie-Claude Maurel, bilans transformacji ekonomicznej i społecznej w Europie Środkowej w okresie postkolektywistycznym. Po zdefiniowaniu ram poznawczych i metodologicznych wspomnianych badań omówimy etapy, które wyznaczają granice czasowe zmiany systemowej - od odejścia od kolektywizmu aż po rekompozycję terenów wiejskich - ze szczególnym uwzględnieniem różnorodności kierunków rozwoju obszarów wiejskich.

Słowa kluczowe: wiejskość, zmiany systemowe, postkolektywizm, trajektoria, koncepcja zależności od ścieżki.

Społeczeństwa Europy Środkowej, motywowane wolą zerwania z systemem komunistycznym i jego ideologią, wstąpiły na drogę przemian systemowych wiodącą ku gospodarce rynkowej i demokracji. Owa zmiana systemowa zapoczątkowała przekształcenia strukturalne, które w ciągu zaledwie dwóch dziesięcioleci gwałtownie i na wiele sposobów zmieniły wieś. $Z$ uwagi na ich natężenie i radykalność zmiany te można porównywać jedynie z przemianami agrarnymi pierwszej połowy wieku XX i kolektywizacją lat 50. Niniejszy artykuł stawia sobie za cel ponowne podjęcie problematyki badań, które nadawały ton analizom transformacji wsi po roku 1989. Mamy tu na myśli sposób konstruowania hipotez badawczych, sposoby doboru przedmiotu i metody prowadzenia badań oraz to, jakie wnioski można na tej podstawie sformułować obecnie. Oznacza to, że nasza perspektywa jest pomyślana jako świadomie refleksyjna, a towarzyszy jej ambicja zrozumienia wpływu transformacji systemowej na światy wiejskie Europy Środkowej ${ }^{1}$.

Marie-Claude Maurel, profesor w EHESS (École des hautes études en sciences sociales), członek Académie d’Agriculture de France, Paryż, Francja.

* Tytuł oryg.: Quand la campagne change de système: trajectoires de la ruralité en Europe centrale.

$1 \mathrm{~W}$ okresie obejmującym ponad dwie dekady śledzenie i analiza owych badań były prowadzone w ścisłej współpracy naukowej przez zespoły kierowane przez Marię Halamską i Marie-Claude Maurel (zob. Bibliografia zamieszczona na końcu tekstu). 


\section{Namysł nad kierunkami ewolucji obszarów wiejskich}

Wieś i wiejskość próbowano zdefiniować wielokrotnie. Sposób budowania pojęcia wsi jako formy materialnej zależy od przyjętego podejścia, które może polegać na opisie jej wyglądu, pomiarach, analizie części składowych oraz funkcji lub próbach uchwycenia jej wyobrażeń pojęciowych. Jednakże wsi nie da się zdefiniować ani jako statycznego obrazu, ani poprzez niezmienne cechy lub właściwości. Jej społeczne wyobrażenia ewoluują w czasie i zmieniają się w przestrzeni w zależności od przyznanego jej miejsca w całości systemu, jej postrzegania przez społeczeństwo i od wartości, które się jej przypisuje. Uważamy, że w najszerszym znaczeniu, mówiąc o wsi, odnosimy się do przestrzeni, która jest fizycznie zobiektywizowana i wyznacza pewną formę przestrzennej organizacji społeczeństw ludzkich.

Aby zrozumieć przemiany wiejskości, należy określić ich miejsce w procesach rozwojowych długiego trwania ${ }^{2}$. Narzuca się tu a priori podejście uwzględniające kategorię procesów rozwojowych i koncepcję zależności od ścieżki (path dependency), jako że uwzględnia ono znaczenie oddziaływania przeszłości, rozumianej jako ciąg następujących po sobie wyborów, podejmowanych przez społeczeństwo w sprawie charakteru instytucji politycznych, ekonomicznych i społecznych. Jednakże - bez pomniejszania roli przeszłości - uwagę należy skierować także na przemiany instytucjonalne, momenty zmiany kierunku bądź rozwidlania się ścieżek rozwojowych, uzależnione od wyborów strategicznych podejmowanych przez aktorów społecznych. Przekształcenia terenów wiejskich są uzależnione od zmian wpływających na system społeczno-ekonomiczny, lecz postępują we właściwym sobie rytmie, na co wpływają ograniczenia nakładane przez zastane formy instytucjonalne. Należy zbadać, jaką rolę - aktywną bądź pasywną - odgrywa dziedzictwo materialne i duchowe okresu socjalizmu i epok wcześniejszych. Przewodnim wątkiem naszych rozważań będzie więc refleksja nad transformacją systemową i jej wpływem na przemianę świata wiejskiego w ich historycznych kontekstach.

\section{Początkowe założenia empiryczne}

Na wstępie procesu transformacji pytano o warunki początkowe wyjścia z kolektywizmu oraz istotę zmiany modelu rolnictwa i wsi. Kraje Europy Środkowej tworzyły zatem „inną Europę”, w znacznej mierze bardziej rolniczą i wiejską w porównaniu z krajami Europy Zachodniej, o czym decydowały struktury powstałe

2 Pojęcie ścieżki rozwojowej narzuca się, gdy mowa o ujęciu czasowego wymiaru procesu transformacji, toteż w namyśle nad przemianami wsi proponujemy bazowanie na nim jako narzędziu pojęciowym. Ważne jest przy tym, by objaśniać wybrane odcinki czasu oraz momenty uznawane za decydujące o rozwidleniu lub zmianach kierunku ścieżek. 
w tych krajach w okresie komunizmu i epokach wcześniejszych ${ }^{3}$. Diagnoza świata wiejskiego ukształtowanego $\mathrm{w}$ trakcie czterech dziesięcioleci kolektywizmu zapowiadała, że transformacja będzie trudna, a niekiedy wręcz niemożliwa. Porzucenie systemu kolektywistycznego odbywało się na drodze demontażu instytucji, które uformowały jego architekturę. Jak zatem zaprojektować i koordynować drogi wyjścia z kolektywizmu agrarnego, manewrując pomiędzy stopniowym adaptowaniem, uwzględniającym minimum istniejących instytucji, a radykalnym dostosowaniem do form organizacyjnych właściwych rolnictwu gospodarek kapitalistycznych? To pytanie doprowadziło na scenie politycznej do sporu na temat różnych koncepcji transformacji ustrojowej i kierunku reform instytucjonalnych. Wybór sposobu zarządzania dekolektywizacją stanowił wyzwanie polityczne i społeczne. Gdy pojawiało się pytanie o wybór alternatywnego modelu rolnictwa, formułowano je przede wszystkim w odniesieniu do zmiany prawa własności i przywrócenia gospodarki rynkowej. Przyszłość, będąca przedmiotem ożywionych debat politycznych, jawiła się jako niepewna. Paradygmat transformacji, inspirujący rozważania teoretyków oraz wybory polityczne nowych rządów, nie wydawał się nam wystarczająco uzasadnioną ramą teoretyczną ${ }^{4}$.

\section{Powroty do miejsc prowadzenia badań}

Przyjęta przez nas metoda miała opierać analizę nadchodzących zmian na badaniach empirycznych. Ich śledzenie polegało na wyborze w każdym z trzech krajów takich miejsc prowadzenia badań, by były one porównywalne ${ }^{5}$. Wyborem tym, podobnie jak powstawaniem zbioru monografii omawiających sytuację na danych obszarach u progu transformacji, kierowały pewne zasady ${ }^{6}$. Do gromadzenia danych pozwalających zrozumieć zachowania aktorów stojących w obliczu nieuchronnego wyjścia z systemu i konieczności dostosowania się do nowej sytuacji zaprojektowano odpowiednie formularze wywiadów. Informacje zbierane podczas każdej wizyty w danym miejscu umożliwiły sprawdzenie zdolności reagowania

3 Cechy systemu kolektywistycznego były odmienne w poszczególnych krajach.

4 W ekonomii i politologii metody badania zmiany systemowej różnią się co do sposobu, w jaki konceptualizuje się w nich ową zmianę - albo przez odniesienie do stanu pożądanego w punkcie dojścia (paradygmat transformacji), albo w perspektywie „ewolucyjnej”, bardziej wrażliwej na kwestie trwania oraz istnienia w czasie instytucji lub praktyk. W niniejszym artykule trzymamy się drugiej z wymienionych perspektyw.

5 Z inicjatywy zespołu francuskiego do sieci badawczej włączono socjologów z trzech państw: Węgier, Czechosłowacji oraz Polski. We wszystkich pracach badawczych ze strony polskiej uczestniczyły Maria Halamska i Elżbieta Piotrowska.

6 Pierwsze monografie dotyczyły gospodarstw spółdzielczych i gospodarstw państwowych, a także ich najbliższego otoczenia. 
aktorów społecznych. Dzięki ich odwiedzaniu w regularnych odstępach czasu możliwe było śledzenie postępów projektów przekształcania dawnych gospodarstw kolektywnych, a także pojawienia się nowych podmiotów gospodarczych i nowych form organizacji. Jednocześnie narzędzia obserwacji zostały rozciągnięte na nowo powstające instytucje samorządu terytorialnego, tak by możliwe było monitorowanie wpływu reform na zbiorowości wiejskie uwolnione spod biurokratycznego systemu zarządzania.

Aby zrozumieć genezę ścieżek rozwojowych na każdym z obszarów, staraliśmy się zbierać informacje pozwalające śledzić przeszłość lokalnych społeczności: od powojennych reform agrarnych i kampanii kolektywizacji aż po niedawne restrukturyzacje okresu komunistycznego (Maurel 1994; [red.] 1994). Prace badawcze były prowadzone tu na dwóch poziomach - krajowym oraz lokalnym. O ile pierwszy z nich pozwalał zrozumieć rolę państwa jako punktu odniesienia dla przynależności do wspólnej historii oraz dyskusji nad sposobem wyjścia $z$ dawnego systemu, o tyle interpretacja prowadzona na poziomie społeczności lokalnych umożliwiała zrozumienie konkretnych odpowiedzi aktorów społecznych na zmiany instytucjonalne, którymi sterowała polityka państwa. Zachowania aktorów społecznych, realizowane przez nich modele ideologiczne, ich zdolność przyjmowania i uczenia się nowych sposobów działania pozwalały zrozumieć procesy różnicowania wynikające z wpływu kontekstu geograficznego (Lamarche, Maurel 1995; Halamska, Maurel 1997).

Stopniowo, w miarę postępujących reform i restrukturyzacji, tematyka badań obejmowała dodatkowe zagadnienia, które wzbogaciły problematykę wyjściową. Dla prześledzenia przyjętych ścieżek rozwojowych niezbędne jest odwoływanie się do szerokich kontekstów. Jednakże ograniczone ramy objętościowe niniejszego artykułu dyktują wybór dwóch wymiarów: z jednej strony restrukturyzacji agrarnej, z drugiej zaś sposobów zarządzania społecznościami lokalnymi. Te dwa - a priori odmienne co do swej natury - wymiary spaja perspektywa, w której pokazujemy ich wzajemne się przeplatanie. Wprawdzie zagadnienia te nie wyczerpują tematu przekształceń wiejskości, ale dostarczają pewnych kluczy do zrozumienia wpływu, jaki miała na nią transformacja ustrojowa. 


\section{Czas zmiany}

\subsection{Drogi wyjścia z kolektywizmu agrarnego}

Zmiana systemowa pociągała za sobą porzucenie kolektywizmu i jego demontaż $\dot{z}^{7}$ Na Węgrzech, podobnie jak w Czechach, nowa władza potraktowała priorytetowo przywrócenie praw własności gruntów i kapitału produkcyjnego ${ }^{8}$, jak również zmianę statusu prawnego dawnych gospodarstw zbiorowych. Na mocy prawa, w proporcjach zmiennych w zależności od kraju, łączono zwrot (i/lub rekompensatę) dóbr odebranych dawnym właścicielom z przyznawaniem nowych praw własności ziemi pracownikom rolnym (lub wiejskim gospodarstwom domowym) i sprzedażą rolnikom gruntów należących do funduszy państwowych (Halamska 1995). Prywatyzacja spowodowała pojawienie się masy niewielkich właścicieli ziemskich o skrajnie odmiennym, jak się okazało, stopniu zainteresowania działalnością rolniczą. Różne sposoby prywatyzacji kapitału produkcyjnego (budynków, żywego inwentarza, materiałów rolniczych) stanowiły część procedur zmiany statusu prawnego spółdzielni produkcyjnych i gospodarstw państwowych. Niezależnie od owych sposobów operacje dekolektywizacji spowodowały rozproszenie trzech czynników produkcyjnych - ziemi, kapitału i pracy - skupionych dotąd w gospodarstwach zbiorowych pod jednym zarządem ${ }^{9}$. Wprowadzenie przepisów demontujących kolektywizm dało początek pierwszemu etapowi transformacji, upływającemu pod znakiem różnorodności sposobów uwłaszczania się na gruntach i środkach produkcji, i stanowiło punkt wyjścia do zarysowania się strategii prywatyzacji i reprywatyzacji (Maurel 1997). Ścieżki przejścia od kolektywizmu ku innym formom społecznym stanowiły temat licznych publikacji (Maurel 1994; Halamska 1998; Halamska, Maurel 2010a). Jak owe postkolektywistyczne formy społeczne mają się do form wcześniejszych, na ile wyraża się w nich pewna ciągłość, na ile zaś stanowią wyraz zerwania z przeszłością? Każdą społeczną formę produkcji definiuje swoiste połączenie trzech, wspomnianych już, czynników produkcji istotnych w rolnictwie: ziemi, pracy i kapitału. Niektóre $\mathrm{z}$ form, powstałe w wyniku niepowtarzalnego

7 System ten obejmował wszystkie aspekty życia gospodarczego i społecznego milionów mieszkańców wsi. Działalność sektora pierwszego (rolnictwo, leśnictwo, rybołówstwo) tworzyło podstawy ekonomiczne kolektywizmu agrarnego, podczas gdy usługi prowadzone przez gospodarstwa zbiorowe pozostawały słabo rozwinięte. Figura chłoporobotnika wędrującego między wsią a fabryką znajdującą się w mieście stanowiła jedyne wcielenie wielozawodowości w środowisku wiejskim.

8 Chodzi tu przywrócenie rzeczywistego prawa własności, obejmującego całość uprawnień (w rozumieniu prawa rzymskiego) - usus, fructus i abusus

9 Dekolektywizacja powinna być pojmowana jako globalny proces, dotyczący trzech istotnych dla rolnictwa czynników produkcji - ziemi, kapitału i pracy, zachodzący w warunkach systemowej zmiany ekonomicznej związanej z przejściem na system gospodarki rynkowej. 
połączenia czynników produkcyjnych, okazują się przejściowe ${ }^{10}$. Dociekanie genezy form społecznych zaliczanych do kategorii postkolektywistycznych wyznaczyło główną oś badań nad fazą eksperymentalnego wprowadzania nowych struktur do rolnictwa. Wielkie gospodarstwa, działające zasadniczo w formie spółdzielni lub spółek (spółek akcyjnych, spółek z ograniczoną odpowiedzialnością), zatrudniają pracowników i produkują wyłącznie na rynek. Rolnictwo rodzinne przybiera natomiast zróżnicowane formy, odmienne ze względu na rozmiar, logikę działalności, orientację produkcji na rynek lub na potrzeby własne.

Gospodarstwa rodzinne powstałe po prywatyzacji korzystają bezpośrednio z odzyskanych majątków, pośrednio zaś czynią użytek z ziemi dzierżawionej. Wielu małym gospodarstwom nisko- i średniotowarowym, o powierzchni mniejszej niż trzy hektary, początek dały dawne działki przydzielane na własny użytek (konsumpcję własną) pracownikom rolnym, a polityka redystrybucji gruntów umożliwiła ich powiększanie. W poszczególnych krajach profile strukturalne różnią się ze względu na stopień koncentracji własności ziemskiej, charakter siły roboczej (rodzinnej i/lub pracowniczej) oraz orientacji produkcji. Rolnictwo czeskie, ze względu na silną koncentrację własności i wykorzystanie pracowniczej siły roboczej, odróżnia się od dwoistego, złożonego z małych i dużych gospodarstw, rolnictwa węgierskiego, podczas gry w Polsce dominują małe i średnie gospodarstwa rodzinne ${ }^{11}$.

Skazany na likwidację system kolektywistyczny ustąpił miejsca uwłaszczeniu opartemu na uznaniu własności prywatnej i regulacyjnej roli rynku, co zmieniło ekonomiczne i społeczne reguły gry. Zmiany te wywołały długotrwałą destabilizację ekonomicznych podstaw wsi. Pierwsze dziesięciolecie okresu postkolektywistycznego charakteryzowało urynkowienie i jego destrukcyjne dla rolnictwa skutki: niepewny los następców gospodarstw zbiorowych, gwałtowny spadek zatrudnienia w rolnictwie, zubożenie dużej liczby mieszkańców terenów wiejskich, skazanych na bezrobocie lub powrót do produkcji na własny użytek. Szok dekolektywizacji dał początek przekształceniom wsi, przy czym już na ich początku dało się zauważyć, że gwałtowne zerwanie ciągłości doprowadzi do powstania przegranych mas i zwycięskiej mniejszości.

10 Dlatego też po kilku latach nowe spółdzielnie właścicieli i przedsiębiorstwa państwowe (powstałe z przekształcenia państwowych gospodarstw rolnych) zmieniły swój status prawny tak, aby ustabilizować kapitał operacyjny i ujednolicić tryb zarządzania.

11 Analiza logik odtwarzania się i adaptacji gospodarstw rodzinnych w Polsce stała się tematem dwóch opracowań: w języku polskim (Halamska, Lamarche, Maurel 2003) i francuskim (Maurel, Halamska, Lamarche 2003). 


\subsection{Reforma samorządu lokalnego i wymiana elit}

Reformy administracji lokalnej, przyjęte i wprowadzone w trzech interesujących nas krajach po 1990 r., doprowadziły do zmian modelu instytucjonalnego. Wpisywały się one w nurt demokratyzacji struktur państwowych, dla którego inspirację stanowiła Europejska Karta Samorządu Lokalnego przyjęta przez Radę Europy w 1985 r. Uznanie zasady samostanowienia i przyznanie samorządom swobód administracyjnych otworzyło drogę dla radykalnej transformacji sposobu funkcjonowania władz lokalnych. Biurokracja i hierarchiczny styl zarządzania charakterystyczne dla gospodarki centralnie sterowanej - ustąpiły miejsca innym metodom koordynowania życia gospodarczego i społecznego. Wyposażone w demokratycznie wybrane organy władzy samorządy lokalne cieszą się osobowością prawną, korzystają z praw własności, dysponują własnymi zasobami i niezależnym budżetem, a prawo przyznaje im określone uprawnienia. Zakres reform wykracza daleko poza uznanie nowych sposobów zarządzania sprawami lokalnymi, a zmiana nie ogranicza się do zbudowania nowych instytucji oraz wymiany dawnych elit. Model samorządu lokalnego zachęca obywateli, zarówno nowo wybrane władze, jak i wyborców, do przyswojenia sobie wartości demokratycznych. Zmianie stosunków władzy w społeczności lokalnej towarzyszy nabywanie umiejętności gry politycznej, której zasady są nieznane większości aktorów społecznych. Proces przyswajania sobie przez wyborców i wybieranych wartości demokratycznych, ich udział w wyborach oraz innych formach zaangażowania politycznego znajdowały się w centrum badań przeprowadzonych przez nasz zespół (Halamska, Maurel 1993). Sposoby, jakimi podczas wyborów w latach 1990, 1994 i 1998 dokonywała się rekompozycja lokalnych scen politycznych, dowodziły, że mechanizmy reprodukcji elit - w części z powodu orientacji politycznych społeczności lokalnych - zatriumfowały, i to pomimo odnowienia składu osób wybieranych (Halamska, 2001). Oto jedna $\mathrm{z}$ dróg konsolidacji demokracji lokalnej ${ }^{12}$.

\section{Czas rekompozycji}

Począwszy od 2000 r., restrukturyzacja agrarna, reorganizacja władzy lokalnej oraz rozprzestrzenianie się nowego modelu lokalnej samorządności przyczyniają się do rekompozycji form wiejskości (Maurel 2005). Otwarcie się obszarów wiejskich na wszechstronną konkurencję gospodarczą przyspiesza reorganizację sektorów rolnego i żywnościowego oraz sprzyja rozkwitowi nowej działalności usługowej,

12 Uwaga ta odnosi się zarówno do trzech gmin w Polsce - Drobina, Stęszewa i Zatora, jak i do niewielkiego węgierskiego miasteczka Bóly, położonego w środkowej części regionu zadunajskiego (Maurel, Pola 2006). 
w szczególności turystyki i rekreacji. Nowe horyzonty otwierają się również przed młodymi, mobilnymi mieszkańcami terenów wiejskich. Niepewna sytuacja mieszkańców wsi, dotkniętych utratą pracy i źródeł dochodów, przyciąga uwagę władz publicznych. Perspektywa wejścia do Unii Europejskiej wymaga od państw kandydujących podjęcia serii zabiegów dostosowawczych, a reguły i normy europejskie narzucają przyjęcie ram prawnych zawartych w dorobku wspólnotowym. Wieś może wówczas korzystać z programów przedakcesyjnych dla krajów kandydujących (PHARE, SAPARD), a następnie, już po wstąpieniu do Wspólnoty w 2004 r., także $\mathrm{z}$ innych form pomocy publicznej finansowanych przez $\mathrm{UE}^{13}$. W odniesieniu do zachodnioeuropejskiego modelu zagospodarowania obszarów wiejskich programy takie wspierają proces dywersyfikacji oparty na odnowie funkcji i wykorzystania obszarów wiejskich, a także rozwoju nowych zasobów gospodarczych. Wspólna Polityka Rolna (WPR) promuje restrukturyzację rolnictwa i zapewnia silne wsparcie dla rozwoju obszarów wiejskich. W ramach drugiego filaru WPR inicjatywy propagujące polityki rozwoju lokalnego, w szczególności europejski model LEADER, przyznają znaczne kwoty finansowania nowym państwom członkowskim. Wdrażanie europejskich instrumentów, zainspirowane polityką transferu modeli, rodzi pytania o ich recepcję przez nowe państwa członkowskie i o ich dostosowanie do krajowych celów (Chevalier, Maurel 2010). Zastosowanie środków proponowanych przez WPR stanowi formę sprawdzianu dla wszystkich zaangażowanych podmiotów (Halamska, Maurel 2010b). Dynamicznym zmianom wsi w jej relacjach politycznych i społecznych towarzyszy stopniowe dostosowywanie się społeczności wiejskich do wymogów lokalnego rozwoju. Dokonuje się również zmiana polegająca na przesunięciu miejsca świata wiejskiego w ramach systemu gospodarczego i powodująca korelatywne odwrócenie społecznych wyobrażeń wiejskości. Ów bezprecedensowy ciąg zmian stał się przedmiotem kolejnej serii wywiadów przeprowadzonych na tych samych co wcześniej obszarach ${ }^{14}$, przy równoczesnym podejmowaniu badań bazujących na danych statystycznych i kartograficznych, pozwalających na uwzględnienie różnorodności ścieżek rozwojowych na poziomie regionalnym (Maurel, Lacquement 2007). Na różnych poziomach - krajowym, regionalnym i lokalnym - dominuje obraz silnego zróżnicowania społeczności i obszarów wiejskich.

13 W związku z wymaganiami UE nowe kraje członkowskie zaproszono do opracowania programów operacyjnych rozwoju wiejskiego. Europeizacja polityk wsparcia publicznego legła u podstaw upowszechnienia się nowego rodzaju zarządzania lokalnego, pociągającego za sobą reorganizację władz na różnych poziomach lokalności (multi-level governance). W powstające na tej drodze partnerstwa angażuje się rosnąca liczba aktorów publicznych (przede wszystkim władz samorządowych) i niepublicznych (organizacje pozarządowe, przedsiębiorcy).

14 Brak tu miejsca na przywołanie licznych prac podejmowanych gdzie indziej, a dotyczących tych samych zagadnień. 


\subsection{Restrukturyzacja postkolektywistyczna}

Począwszy od 2004 r., z powodu stosowaniu mechanizmów WPR struktury agrarne przechodzą kolejną fazę rekompozycji. Z jednej strony, proces koncentracji gruntów w bardzo dużych gospodarstwach jest stymulowany zachętami wynikającymi z uproszczonego systemu dopłat bezpośrednich, z drugiej zaś strony dochodzi do gwałtownych zmian w dziedzinie własności gruntów (zwłaszcza za sprawą licytacji gruntów pochodzących z zasobów publicznych). Drobni użytkownicy gruntów, którzy doświadczyli destabilizujących skutków prywatyzacji systemu rolno-spożywczego, nie są w stanie skorzystać z dobrodziejstw wsparcia WPR dla gospodarstw średniotowarowych. We wszystkich nowych państwach członkowskich notuje się w kategorii gospodarstw małych największe spadki, zarówno pod względem liczby, jak i użytkowanej powierzchni rolnej, zaznacza się natomiast konsolidacja własności gruntów w dużych gospodarstwach. Ewolucja gospodarstw średnich przebiega w sposób bardziej zróżnicowany - powyżej pewnego progu powierzchni (20 ha) liczba i relatywne znaczenie takich gospodarstw rosną.

W procesach restrukturyzacji agrarnej zaznaczają się pewne tendencje. Przywrócenie rolnictwa typu rodzinnego nie było drogą obieraną przez kraje Europy Środkowej, które przeszły pełną kolektywizację (Maurel 2015). Utrata typowo chłopskich umiejętności i wiedzy, niedostatek kapitałów i sieci wsparcia technicznego oraz brak organizacji zawodowych wpłynęły hamująco na formowanie się nowoczesnego i stabilnego modelu rolnictwa rodzinnego. W tych warunkach wzór rolnictwa rodzinnego, przedstawiany jako „dominujący w Europie model działalności”, okazał się niedostosowany do form organizacji większości postkolektywistycznych gospodarek rolnych, a także nieodpowiedni dla wspierania konsolidacji małych gospodarstw wiejskich rodzin. Mechanizmy „zależności ścieżek rozwojowych" działały na korzyść podtrzymania ciągłości wielkich struktur agrarnych, które - jako niezmienny element odwzorowywujący sposób użytkowania ziemi ponownie narzuciły wspomnianemu modelowi swoją logikę (Maurel 2012). Proces dekoncentracji własności gruntów, który podążał w ślad za przekształcaniem się struktur kolektywnych w rozmaite formy społeczne typu spółdzielczego, stowarzyszeniowego lub przedsiębiorczego, ulegał stopniowemu odwróceniu pod wpływem działania sił ekonomicznych negatywnie selekcjonujących najmniej opłacalne $\mathrm{z}$ wymienionych form społecznych. Sytuacja własnościowa postkolektywistycznych gospodarek rolnych pozostaje paradoksalna: skrajne rozdrobnienie własności ziemskiej pozostaje w sprzeczności ze wzorem użytkowania ziemi, charakteryzującym się względną koncentracją własności w rękach wielkich przedsiębiorstw rolniczych. Większość ich gruntów pozostaje w użytkowaniu pośrednim, a typy koncentracji gruntów różnią się w zależności od cech rynku obrotu ziemią. Proces powiększania 
bazy gruntowej wielkich gospodarstw postępuje z nieoczekiwaną siłą, gdy wziąć pod uwagę sytuację rozdrobnienia własności gruntów. Droga ponownego uwłaszczenia tysięcy drobnych posiadaczy okazała się iluzją, skoro strategia przejmowania ziemi przez wielkoskalowe rolnictwo zorientowane na zysk prowadzi do ich nieuchronnego wywłaszczania ${ }^{15}$. W Europie Środkowej, poza kilkoma wyjątkami, dochodzi do ponownego, mającego podstawę w procesach długiego trwania, uwydatnienia się dualizmu agrarnego (np. na Węgrzech i w Czechach).

\section{6. Ścieżki rozwoju samorządu terytorialnego}

Od początku transformacji stawiano hipotezy, w myśl których siły i mechanizmy gospodarki wolnorynkowej doprowadzą do ponownego i silnego zróżnicowania terytorialnego. Nieuregulowane, a zarazem selektywne oddziaływanie rynku odbija się przede wszystkim na obszarach wiejskich, bezpośrednio wpływając na ich relatywne umiejscowienie w przestrzeni, a także wartość i znaczenie pozostających w ich dyspozycji zasobów materialnych i niematerialnych. Odpowiedź na te zmiany przypadła w udziale społecznościom lokalnym, co każe zbadać, z jednej strony, rolę ich potencjału transformacyjnego, z drugiej zaś - sposób działania władz lokalnych.

Termin „potencjału transformacyjnego” obszaru został wprowadzony w celu nazwania „kombinacji czynników określających jego zdolność do przyjęcia warunków transformacji postkomunistycznej" (Illner 1995, s. 9). W definicji tej wyraża się myśl, zgodnie z którą zdolność do reakcji zależy od zbioru uwarunkowań i cech właściwych danemu obszarowi (Gorzelak 1998). Czynniki określające potencjał transformacyjny ulegają modyfikacji przez sam fakt zmiany systemu ekonomicznego. Czynniki te - poziom wykształcenia i przygotowania zawodowego siły roboczej, stopień integracji społecznej, przedsiębiorczość, stosunek do pracy, kultura polityczna - mają w pierwszym rzędzie charakter społeczny i definiują zdolności adaptacyjne mieszkańców. Na poziomie ekonomicznym czynniki te obejmują poziom rozwoju infrastruktury, zróżnicowania funkcji ekonomicznych, stosunek zanikających i rozwijających się form gospodarczych itd. Spośród czynników należących do porządku geograficznego, a wpływających zasadniczo pozytywnie na potencjał transformacyjny, należy wymienić dobrą jakość środowiska naturalnego, obecność atrakcji turystycznych, niewielką odległość od ośrodków miejskich i wielkich osi komunikacyjnych. Jednakże o wartości potencjału zasobów i przewagach

15 Rynek obrotu ziemią przez długi czas pozostawał mało ożywiony, ale obecnie ulega gwałtownym zmianom wynikającym z zakończenia okresu moratorium na sprzedaż ziemi cudzoziemcom. Gromadzeniu gruntów przez duże struktury produkcyjne (agroholdingi) sprzyja sytuacja na rynku gruntów, gdzie brak interwencji państwa ułatwia omijanie obowiązujących reguł. 
konkurencyjnych społeczności lokalnej decydują dwa czynniki - sposób zarządzania nią oraz kapitał relacji społecznych. Dlatego też kluczowe znaczenie ma zdolność społeczności wiejskich do organizowania się w sieci współpracy i partnerstw opartych na kapitale społecznym, do projektowania strategii rozwoju i budowania nowych zasobów (Halamska 2009).

Pojawienie się zdecentralizowanego sposobu sprawowania rządów zachęciło władze i zbiorowości lokalne do samodzielnego poszukiwania sposobów dostosowania się do nowych warunków. Aby rozwinąć się w pełni, ten nowy sposób zarządzania wymaga warunków sprzyjających demokratycznemu udziałowi w życiu politycznym. Jednakże podstawa, na której opiera się rozwój społeczeństwa obywatelskiego, jest złożona. Jej korzenie sięgają zasobu idei, wartości i wyobrażeń, które tworzą kulturę polityczną danego społeczeństwa. Pojęcie kultury politycznej odnosi się przy tym nie tylko do wartości odziedziczonych, przenika także wszystkie relacje władzy i wyraża się przez zachowania i praktyki. Te ostatnie zaś podlegają reinterpretacji pod wpływem doświadczeń życiowych społeczeństwa i zmieniają się powoli, potrzebując czasu na dostosowanie się do zmiany reguł gry politycznej. Jak doprowadzić do zaistnienia demokracji lokalnej, skoro odniesienia poznawcze aktorów społecznych naznaczone są przez inne logiki sprawowania władzy? Oddziaływanie dziedzictwa mentalnego socjalizmu, trwałość nieadekwatnych zachowań i praktyk (paternalizmu, uprzywilejowania, a nawet korupcji) przyczynia się do spowolnienia upowszechniania się wartości demokratycznych. Przyswajanie demokratycznego i partycypacyjnego sposobu rządzenia łączy w sobie procesy adaptacji i oporu, będące w części zależne od posiadanych przez społeczności lokalne zasobów kapitału społecznego. To one właśnie decydują o zdolności do rządzenia się, czyli rządności (Maurel, Halamska 2006).

\subsection{Nowe oblicza wsi}

Dzieląc podobny los, obszary wiejskie w Europie Środkowej przechodzą fazę rekonfiguracji zachodzącą według różnych trajektorii, wynikających z odnowy funkcji przestrzennych i waloryzacji nowych zasobów ekonomicznych. Zmiana ta, polegająca na transformacji wartości użytkowych przestrzeni wiejskiej i przekształceniu oblicza wsi, przebiega odmiennie w zależności od miejsca (Lacquement, Maurel, Raynal 2011).

Otwarcie granic zwiększa liczbę turystów na obszarach wiejskich najkorzystniej położonych ze względu na pozyskiwanie nowej klienteli (najczęściej przybywającej z krajów członkowskich UE). Na obszarach wiejskich osiedlają się nowi, stali lub tymczasowi mieszkańcy, przybycie zaś inwestorów powołuje do życia nowe aktywności gospodarcze, które zastępują działalność wygasającą. 
Przetrwanie działalności przemysłowej jest możliwe we wsiach o przewadze ludności robotniczej, powstałych dzięki kompleksom przemysłowym epoki socjalizmu. W sytuacji spowolnienia gospodarczego dostosowanie systemów produkcyjnych do wymagań rynku odbywa się kosztem zmniejszenia zatrudnienia i prowadzi do selektywnego przenoszenia produkcji. Nowe rodzaje inwestowania, zależne najczęściej od zewnętrznych ośrodków decyzyjnych, kierują się ku funkcjom podwykonawczym, realizowanym przez małe i średnie przedsiębiorstwa, korzystające $z$ inwestycji zewnętrznych i/lub inicjatyw endogennych. Jednak całe obszary świata wiejskiego, zbyt oddalone od centrów dyfuzji, pozostają z dala od czynników dynamizujących integrację gospodarczą, a inercja odziedziczonych struktur i brak lokalnych strategii rozwoju pogłębiają ich marginalizację. Zdolność do powstrzymywania upadku obszarów wiejskich rozkłada się nierównomiernie na poszczególnych obszarach, a rozwój jest mało prawdopodobny na terenach, których gospodarkę okaleczył kryzys transformacyjny. Możliwe jest natomiast zachęcanie do tworzenia nowych zasobów poprzez skoordynowane działania inicjatyw lokalnych. Osiągnięcia samorządów lokalnych w dziedzinie działań publicznych i rozwoju lokalnego okazują się bardzo zróżnicowane. Zmiany społeczno-gospodarcze wytyczyły odmienne ścieżki, których przebieg był zależny zarówno od odziedziczonych struktur przestrzennych, jak i form zaangażowania społeczności lokalnych $\mathrm{w}$ procesy przemian i specjalizacji funkcjonalnej.

\section{Czas próby}

$\mathrm{Na}$ styku polityk europejskich oraz oddolnych inicjatyw wychodzących od aktorów lokalnych (wybieralnych urzędników, liderów projektów itd.) nowe możliwości rozwoju obszarów wiejskich przyczyniają się do zmiany sposobu zarządzania (ang. multi-level governance, zarządzanie wielopoziomowe). Wprowadzenie europejskiego modelu LEADER zapoczątkowało czas nauki i próby w nowych krajach członkowskich, które wstąpiły do UE w 2004 r. Metoda LEADER, oparta na oddolnej logice działań publicznych, wprowadziła ich nowe mechanizmy, które przyznały uprzywilejowaną rolę podziałowi obowiązków między aktorów instytucjonalnych i społeczeństwo obywatelskie. To podejście, zintegrowane i opierające rozwój na podstawie terytorialnej, polega na skierowaniu wysiłków i inwestycji na projekty zrodzone na poziomie społeczności wiejskich mające na celu wzmocnienie inicjatywności aktorów lokalnych i przyczynia się do powstania typu zarządzania sprzyjającego wspieraniu demokracji lokalnej i partycypacyjnej.

Czy rozpowszechnianie się modelu rozwoju endogennego, bazującego na atutach właściwych poszczególnym obszarom i mobilizacji inicjatyw podejmowanych przez zdecentralizowane podmioty, odegrało rolę katalizatora procesów europeizacji 
obszarów wiejskich? Jakie czynniki ułatwiały, a jakie utrudniały transfer modelu LEADER, jak przyjmowali go poszczególni aktorzy lokalni? Próbę odpowiedzi na te pytania podjęto $\mathrm{w}$ ramach projektu badawczego ALDETEC ${ }^{16}$.

Presja adaptacyjna wywierana przez UE jest różnorodnie odbierana i wdrażana, przekładając się na zróżnicowane logiki działania. Elementy instytucjonalne i kultury polityczne specyficzne dla poszczególnych aktorów wpływają na przyjmowanie europejskich norm i polityk, przyczyniając się do zróżnicowania ich logiki. Państwa zarządzają zatem implementacją narzędzi LEADER jako instrumentu towarzyszącego albo instrumentu interwencji. Na poziomie lokalnym współdziała on z lokalną społecznością, jej stosunkami społecznymi, elitami i zasobami, a przyswajanie recept instytucjonalnych dokonuje się według logiki właściwej każdej z Lokalnych Grup Działania (LGD). Proces ich przyjmowania jest uzależniony w znacznej mierze od mobilizacji elit i ich wyobrażeń o przydatności owych recept dla rozwiązywania lokalnych problemów. Chociaż wdrażanie instrumentów LEADER pozostaje zasadniczo $\mathrm{w}$ gestii wybieranych przedstawicieli i menedżerów, to jednak słaba znajomość jego zasad, ograniczająca się często do garstki aktorów społecznych, oraz ich skromne zaangażowanie w przygotowanie strategii i projektów uwydatnia ograniczenia transferu tej polityki (Halamska, Michalska, Śpiewak 2010). Zestawienie logiki działania na poziomie krajowym i sposobu przyswajania na poziomie lokalnym pozwala określić typowe sytuacje występujące w odniesieniu do LGD objętych naszymi badaniami terenowymi (Chevalier, Maurel 2013).

Tabela 1. Interpretacja logik transferu modelu LEADER

Table 1. Interpretations of the LEADER model logic of transfer

\begin{tabular}{lll}
\hline & \multicolumn{1}{c}{$\begin{array}{c}\text { Logika państwa jako } \\
\text { czynnika towarzyszącego }\end{array}$} & Logika interwencji państwowej \\
\hline $\begin{array}{l}\text { Przyswajanie rozszerzone na } \\
\text { różnorodnych aktorów lokalnych }\end{array}$ & Wchłonięcie modelu & Adaptacja modelu \\
$\begin{array}{l}\text { Stopień przyswojenia ograniczony } \\
\text { do elity }\end{array}$ & Adaptacja modelu & Opór lub bezwładność \\
\hline
\end{tabular}

Źródło: Chevalier, Maurel 2013, s. 49.

Source: Chevalier, Maurel 2013, s. 49.

16 W projekt badań podstawowych ALDETEC (fr. Action locale et développement territorial en Europe centrale; Akcja lokalna i rozwój terytorialny w Europie Środkowej), koordynowany przez Marie-Claude Maurel i Pascala Chevalier, zaangażowanych było dziesięcioro uczonych środkowoeuropejskich oraz ich zespoły związane, między innymi, z Ośrodkiem Studiów Regionalnych Akademii Nauk w Pécs, Polską Akademią Nauk w Warszawie oraz Francuskim Ośrodkiem Badawczym Nauk Społecznych w Pradze. 


\section{Wnioski}

W zakończeniu niniejszej skróconej, retrospektywnej analizy można pokusić się o sformułowanie kilku wniosków.

Dotyczą one przede wszystkim zastosowanej metody. Ponawiana wielokrotnie obserwacja tych samych obszarów pozwoliła zgromadzić dane empiryczne o niewątpliwie bezprecedensowym zakresie. Takie badania, oparte na dokładnym rozpoznaniu tych samych miejsc, umożliwiają interpretację ścieżek przemian wsi i uprawomocnienie metod o charakterze bardziej teoretycznym przez ich konfrontację $\mathrm{z}$ faktami.

Metody te zostały następnie zastosowane do badania procesów przemian wsi, które można było śledzić oraz interpretować w ich wielu wymiarach: społecznym, gospodarczym i terytorialnym. Uzyskane wyniki zachęcają do ponownego zbadania roli dziedzictwa przeszłości oraz natury „zależności” od ścieżek rozwojowych (path dependency). Ważne jest tu pytanie, w jaki sposób zmiana ustrojowa może być postrzegana i przyjmowana przez aktorów społecznych. W ramach ruchu społecznej restratyfikacji, który objął społeczeństwo wiejskie (Halamska 2016a; 2016b), poszczególne osoby i całe gospodarstwa domowe mogą uważać się - w kategoriach pozycji społecznej i wysokości dochodów - za jego wygranych lub przegranych. Znaczna część ludności wiejskiej znalazła się w sytuacji społecznej deklasacji, podsycającej frustrację i poczucie niesprawiedliwości. Nostalgia za wyidealizowaną przeszłością i pokusa powrotu do minionych czasów mogła zatem trafić na podatny grunt i dawać pożywkę reakcjom polegającym na odrzuceniu form będących wynikiem przemian.

Należy wreszcie zapytać, czy kierunek zidentyfikowanych ścieżek rozwojowych wsi jest zbieżny z kierunkiem analogicznych ścieżek, które daje się obserwować w starych krajach członkowskich UE (Maurel 2004), czy też rozbieżny, polegając na odnawianiu się cech wsi swoistych dla krajów Europy Środkowej. Pewne postawy wobec europejskich inwestorów ${ }^{17}$ i sygnały oporu wobec procesu europeizacji napływające ze strony krajowych kultur politycznych wskazują na istnienie ślepych uliczek transferu modelu instytucjonalnego. Czy „rewolucje konserwatywne”, dokonujące się obecnie na Węgrzech i w Polsce, zwiastują ponowne rozejście się ścieżek?

tłum. Michał Wójtowski

17 Niedawno przyjęte na Węgrzech i w Polsce przepisy dotyczące obrotu ziemią wprowadzają reglamentację praw własności i użytkowania instrumentem kontrolnym mającym przeciwdziałać penetracji rynku jedynie przez inwestorów europejskich. 
Gdy zmienia się system. Ścieżki rozwoju wiejskiego w Europie Centralnej

\section{Bibliografia}

Chevalier P., Maurel M.-C. (2010). LEADER w krajach Europy Środkowej. Mechanizmy transferu modelu rozwoju lokalnego. Wieś i Rolnictwo, 4 (149), 26-41.

Chevalier P., Maurel M.-C. (2013). The LEADER programme in Central Europe: A new local development policies. Acta Universitatis Lodziensis, Folia Sociologica, 44, 39-52.

Gorzelak G. (1998). Regional and Local Potential for Transformation in Poland. Warszawa: EUROREG.

Halamska M. (1995). La difficile reconversion de l'agriculture étatique en Pologne. Revue d'Etudes comparatives Est-Ouest, 26, 91-118.

Halamska M. (1997). Decollectivisation of agriculture in Central Europe: the first regularities of the process. Eastern European Countryside, 3, 7-19.

Halamska M. (1998). Dekolektywizacja rolnictwa w Europie Środkowej i jej społeczne konsekwencje. Warszawa: Instytut Rozwoju Wsi i Rolnictwa PAN.

Halamska M. (2001). Reprodukcja czy wymiana? Przekształcenia lokalnych elit politycznych w Polsce w latach 1990-1998. Warszawa: Wydawnictwo Naukowe Scholar.

Halamska M. (2008). Lavenir des petites exploitations agricoles et de leurs propriétaires. W: M. Halamska (red.). L'agriculture française et l'agriculture polonaise dans l'Europe de 2007: expériences partagées et intérets communs? (s. 38-56). Varsovie-Paris: Centre de l'Académie Polonaise des Sciences.

Halamska M. (2009). Social capital of rural areas: Attempt at reconstruction. Przegląd Socjologiczny, 4 (57), 69-94.

Halamska M. (2016a). Processes of change in the social structure of Poland's rural population in the years 1991-2013. Wieś i Rolnictwo, 4 (173), 81-99.

Halamska M. (2016b). Struktura społeczno-zawodowa ludności wiejskiej w Polsce i jej przestrzenne zróżnicowanie. Wieś i Rolnictwo, 1 (170), 59-85.

Halamska M., Lamarche H., Maurel M.-C. (2003). Rolnictwo rodzinne w transformacji postkomunistycznej. Anatomia zmian. Warszawa: Instytut Rozwoju Wsi i Rolnictwa PAN.

Halamska M., Maurel M.-C. (1993). Proces przekształceń lokalnych elit politycznych w Polsce. Wieś i Rolnictwo, 1, 67-93.

Halamska M., Maurel M.-C. (1997). The Farmers of Europe: Differences of views, attitudes, identities. Polish Sociological Review, 1, 59-74.

Halamska M., Maurel M.-C. (2010a). Decollectivisation of agriculture and reshaping of agrarian structure in Central Europe. Przegląd Socjologiczny, 59 (2), 29-56.

Halamska M., Maurel M.-C. (2010b). Les acteurs locaux à l’épreuve du modèle européen. France, Hongrie, Pologne. Praga: CEFRES, Instytut Rozwoju Wsi i Rolnictwa PAN.

Halamska M., Michalska S., Śpiewak R. (2010). LEADER w Polsce. Drogi implementacji programu. Wieś i Rolnictwo, 4 (149), 104-119.

Illner M. (1995). Les conséquences sur le plan territorial du changement politique et économique en République tchèque. Cahiers du CEFRES, 9, 19-36.

Lacquement G., Maurel M.-C., Raynal J.-C. (2011). Trajectoires d’une ruralité recomposée en Europe centrale. Economie rurale, 325-326, 39-53. 
Lamarche H., Maurel M.-C. (1995). Transitions agraires en Europe centrale. Etudes rurales, Année, 138-140.

Maurel M.-C. (1994). La transition post-collectiviste. Mutations agraires en Europe centrale. Paris: L'Harmattan.

Maurel M.-C. (1997). Stratégies d’appropriation de la terre et du capital dans les agricultures centre-européennes. W: A. Olivier (red.). Pưvodní a noví vlastníci (Anciens et nouveaux propriétaires) (s. 14-24). („Cahiers du CEFRES” nr 11). Praga.

Maurel M.-C. (2004). Les enjeux des mutations des territoires ruraux. L'improbable convergence vers un modèle agricole européen. W: B. Chavance. De la transformation post-socialiste à l'intégration européenne (s. 147-180). Paris: L'Harmattan.

Maurel M.-C. (2005). Temps de recomposition des territoires ruraux en Europe centrale. Retour sur une expérience de terrain. Revue d'études comparatives Est-Ouest, 36 (2), $5-38$.

Maurel M.-C. (2012). La grande maille agraire en Europe centrale: un invariant spatio-temporel? Etudes rurales, 190, s. 25-48.

Maurel M.-C. (2015). From disappearance to recovery: Family farming in Central Europe. Questioning the path dependency hypothesis. Wieś i Rolnictwo, 1, 79-106.

Maurel, M.-C. (red.) (1994). Les décollectivisations en Europe centrale. T. 2. Itinéraires de privatisation. „Espace Rural”, nr 33, Montpellier.

Maurel M.-C., Chevalier P., Lacquement G. (2014). Transfert et apprentissage du modèle LEADER en Europe centrale. Paris: L'Harmattan.

Maurel M.-C., Halamska M. (2006). Démocratie et gouvernement local dans la Pologne rurale. Paris: CNRS éditions.

Maurel M.-C., Halamska M., Lamarche H. (2003). Le repli paysan. Trajectoires de l'aprèscommunisme en Pologne. Paris: L'Harmattan.

Maurel M.-C., Lacquement G. (2007). Agriculture et ruralité en Europe centrale. Paris: Aux lieux d’être-CEFRES.

Maurel M.-C., Pola P. (2010). Lémergence du développement local le cas de Bóly en Transdanubie méridionale. W: M. Halamska, M.-C. Maurel. Les acteurs locaux à l,épreuve du modèle européen LEADER: France, Hongrie, Pologne (s. 149-184). Prague: CEFRESInstytut Rozwoju Wsi i Rolnictwa PAN. 


\title{
When the System Changes: Rural Development Paths in Central Europe
}

\begin{abstract}
The article presents an economic and social assessment of the post-collectivist period in Central Europe based on the research work conducted in closed cooperation by Maria Halamska and Marie-Claude Maurel. After defining the methodological and epistemological conditions underlying fieldwork, the study retraces temporal stages of the system change, from the time of decolectivisation to the reshaping of rural areas, underlining the diversity of the rural trajectories.
\end{abstract}

Keywords: rurality, system change, post-collectivism, trajectory, path dependency. 